\title{
The potential and challenges of alternative sources of $\beta$ cells for the cure of type 1 diabetes
}

\author{
Monia Cito ${ }^{1}$, Silvia Pellegrini ${ }^{1}$, Lorenzo Piemonti,2 and Valeria Sordi ${ }^{1}$ \\ 'Diabetes Research Institute, IRCCS San Raffaele Scientific Institute, Milan, Italy \\ ${ }^{2}$ Vita-Salute San Raffaele University, Milan, Italy
}

Correspondence should be addressed to V Sordi: sordi.valeria@hsr.it

\begin{abstract}
The experience in the field of islet transplantation shows that it is possible to replace $\beta$ cells in a patient with type 1 diabetes (T1D), but this cell therapy is limited by the scarcity of organ donors and by the danger associated to the immunosuppressive drugs. Stem cell therapy is becoming a concrete opportunity to treat various diseases. In particular, for a disease like T1D, caused by the loss of a single specific cell type that does not need to be transplanted back in its originating site to perform its function, a stem cell-based cell replacement therapy seems to be the ideal cure. New and infinite sources of $\beta$ cells are strongly required. In this review, we make an overview of the most promising and advanced $\beta$ cell production strategies. Particular hope is placed in pluripotent stem cells (PSC), both embryonic (ESC) and induced pluripotent stem cells (iPSC). The first phase $1 / 2$ clinical trials with ESC-derived pancreatic progenitor cells are ongoing in the United States and Canada, but a successful strategy for the use of PSC in patients with diabetes has still to overcome several important hurdles. Another promising strategy of generation of new $\beta$ cells is the transdifferentiation of adult cells, both intra-pancreatic, such as alpha, exocrine and ductal cells or extra-pancreatic, in particular liver cells. Finally, new advances in gene editing technologies have given impetus to research on the production of human organs in chimeric animals and on in situ reprogramming of adult cells through in vivo target gene activation.
\end{abstract}

\author{
Key Words \\ - diabetes \\ - stem cells
}

\section{Introduction}

Type 1 diabetes (T1D) is an autoimmune disorder characterized by insulin-producing $\beta$ cell death caused by autoreactive $\mathrm{T}$ cells (1). T1D contributes to $10 \%$ of the total 422 million diabetes cases worldwide. Although T1D is no more considered to be restricted to children and adolescents, it is one of the most common chronic diseases of childhood, and its incidence is constantly increasing; if incidence rates continue to increase on their existing path, global incidence could double over the next decade (for review see (2)).

Since 1922, exogenous insulin administration has been the most important lifesaving intervention for all T1D patients; however, chronic insulin treatment is a double-edged sword since it fails to prevent longterm complications like ketoacidosis, kidney failure, cardiovascular diseases, neuropathy and retinopathy (3). The only possible definitive cure for this disease consists in providing a new $\beta$ cell source capable of assessing blood sugar levels and secrete insulin in a glucose-dependent manner.

In the last 20 years, allogenic islets transplantation has been considered, in combination with a glucocorticoidfree immunosuppression, an unbeaten cell therapy approach for T1D patients reporting an excellent glucose control, improvement of chronic complications and quality of life (4). However, despite these promising http://www.endocrineconnections.org https://doi.org/10.1530/EC-18-0012
○ 2018 The authors Published by Bioscientifica Ltd
This work is licensed under a Creative Commons Attribution-NonCommercial-NoDerivatives 4.0 International License. 
results, islets transplantation remains a limited therapy approach, due to the shortage of cadaveric donors, the variability of isolated human islets and the need for lifelong immunosuppression. Different approaches using stem cells to support islet survival and function are being explored in preclinical and clinical settings (5). Now, the most advanced strategies to solve these limitations are focused on embryonic/induced PSCs differentiation, reprogramming of adult somatic cells, and, more recently, generation of human organs with a chimera's approach and gene therapy to induce in vivo target gene activation (Fig. 1). This review describes the most important $\beta$ cell replacement approaches that have been developed over the last decades focusing on their progresses, challenges and limits.

Unlimited pancreatic $\beta$ cell source requirement fostered studies on differentiation of pluripotent stem cell (PSC) into functional insulin-secreting cells. Embryonic stem cells (ESC) and induced PSCs (iPSC) have been eligible as new potential candidates to reach this goal due to their differentiation potential and their unlimited proliferation capacity maintaining an undifferentiated state (self-renewal) (6).

In 2006, Novocell (currently ViaCyte, Inc.) developed for the first time an efficient in vitro protocol to differentiate ESC into insulin-producing cells mimicking in vivo pancreatic organogenesis. Novocell's ESC-derived $\beta$ cells yielded up to $7 \%$ insulin content but cells were not able to respond to glucose stimulation, essential properties of bona fide $\beta$ cells, due to their functional immature state (7). Two years later, they reported a novel differentiation approach transplanting ESC-derived pancreatic endoderm cells into immunodeficient mice obtaining, after a 3-month period of spontaneous in vivo differentiation and maturation, glucose-responsive endocrine cells. In fact 3 months after implant, the levels of human insulin in the sera of mice were sufficient to fully protect mice against streptozotocin (STZ)-induced

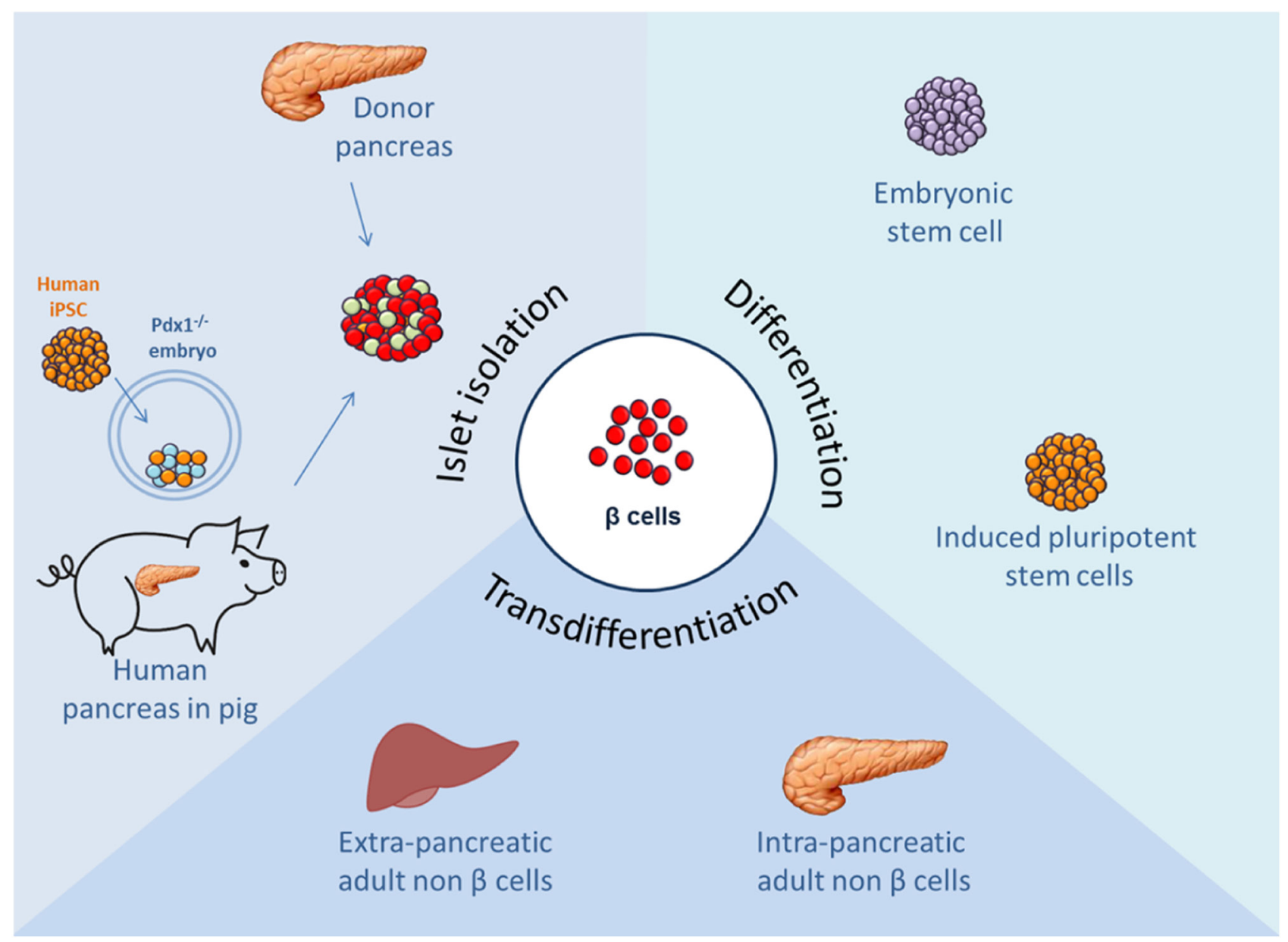

Figure 1

Schematic representation of the most promising sources of pancreatic $\beta$ cells.

$$
\begin{array}{lr}
\text { http://www.endocrineconnections.org } & \odot 2018 \text { The authors } \\
\text { https://doi.org/10.1530/EC-18-0012 } & \text { Published by Bioscientifica Ltd }
\end{array}
$$


hyperglycemia (8). These findings laid the groundwork for the first clinical trial in phase I/II started in 2014 (ClinicalTrials.gov identifier: NCT02239354) by ViaCyte. Shortly, human ESC-derived pancreatic progenitors (named PEC-01) were encapsulated into an immuneprotecting medical device (named Encaptra drug delivery system) and transplanted in a small cohort of T1D patients. This trial aims to evaluate safety, long-term tolerability and efficacy of this system and the results are expected to be published soon.

Over the last 10 years, multiple variations have been made to the ViaCyte initial protocol in order to obtain an enrichment of pancreatic endocrine end products from differentiation of PSC in vitro. The most promising protocols were published in $2014(9,10)$ showing improvements in insulin secretion capacity of PSC-derived pancreatic cells. Rezania and colleagues described a sevenstage in vitro differentiation protocol that led to efficient ESC conversion into glucose-responsive insulin-producing cells. Indeed, in a static in vitro glucose-stimulated insulin secretion, these cells showed an insulin secretion pattern close to human islets and reversed diabetes in two months after transplantation in STZ-induced diabetic mice (9). In parallel, Melton's group developed a different strategy using a three-dimensional cell culture system obtaining mature, mono-hormonal and functional stem cellderived $\beta$ cells. After only two weeks from transplantation, production of human insulin ameliorated hyperglycemia in NRG-Akita mice (10).

The main difference between these outstanding works consist indeed in the degree of maturation of the implanted cells and in the consequent timing of reversion of the disease: (i) ESC-derived pancreatic progenitor cells from ViaCyte require a 3-month period of in vivo maturation in mice to restore normoglycemia, (ii) mature pancreatic $\beta$ cells from Rezania and colleagues are able to secrete insulin only after a 40-day period of further maturation in vivo, while (iii) functional $\beta$ cells from Melton's group ameliorated hyperglycemia after only two weeks. Whether it is better to transplant mature $\beta$ cells or pancreatic progenitor cells capable of high efficiency in vivo differentiation is still under discussion and the results of ongoing clinical trials with pancreatic progenitor cells will provide an important point on this issue. Of course, the choice of cells at different stages of maturation has implications also on the safety issue, since it is assumed that cells at the stage of progenitors have a greater proliferative capacity and a certain degree of residual plasticity, which should drastically decrease in mature differentiated cells, making these last ones safer.
Despite these encouraging study results, several problems remain associated with the use of ESC: mainly the moral sensitivity regarding the use of human embryos for the production of ESC lines and the immune rejection of these cell lines by recipients in case of transplantation. To overcome these problems, in 2007, human pluripotent cells have been generated from somatic cells thanks to the world-renowned Yamanaka's reprogramming protocol (11). From then onward, in parallel with ESC, several protocols have been published to differentiate human iPSC derived from healthy or diabetic patients into pancreatic $\beta$ cells with encouraging results $(10,12,13$, 14). This approach could lead to 'personalized' therapies preventing allogeneic graft rejection. Autologous PSCs could be obtained by generation of iPSC from somatic cells of subjects with T1D (15) or by transfer of somatic cell nuclei into oocytes that give rise to PSCs that are consistently equivalent to ESC $(16,17)$. PSCs obtained from both these technologies were shown to be able to efficiently differentiate into insulin-producing cells $(12,18)$. However, therapeutic approach using in vitro or in vivo-differentiated PSC is still a big question mark due to the possibility of tumor formation, secondary to residual anarchical undifferentiated cells at the last stage of pancreatic $\beta$ cell differentiation $(8,19)$ and to the auto/alloimmune reaction against engrafted PSC-derived $\beta$ cells.

In particular, safety of the final cell product remains a major issue to be considered to achieve a PSC-based transplantation therapy. Possible solutions include generation of safer iPSC lines, purification of the differentiated cells or cell encapsulation into medical devices. The most promising strategies at the moment are:

1. Non-viral and non-integrating gene delivery methods (transposons, protein transduction and RNA/miRNA transfection) for somatic cells reprogramming into PSC that decrease random transgene insertion into the host genome compared to previous retrovirus and lentivirus transduction (for review see (20)). With these strategies, it is possible to obtain iPSC without transgene integrations so as to avoid insertional mutagenesis, and residual expression and reactivation of reprogramming factors.

2. Identification of surface markers that allow the selection of the desired cell population or the deletion of unwanted cells like residual pluripotent cells. The first effort came from ViaCyte that identified CD142 (Tissue Factor) as a novel surface marker for the selection of pancreatic progenitor cells obtained through the 
differentiation of ESC to increase purity; CD142+ cells transplanted in vivo give rise to all the pancreatic lineages, including functional insulin-producing cells (21). Other groups proposed alternative markers in the last years $(22,23)$, but the most recent and promising pancreatic progenitor cell surface marker identified is the pancreatic secretory granule membrane major glycoprotein 2 (GP2). GP2 is expressed in combination with NKX6.1 and PTF1 $\alpha$, key transcription factors in pancreas development, and it was demonstrated that hPSC-derived $\mathrm{GP}^{+}$cells, differentiated in pancreatic progenitors expressing high levels of NKX6.1, generate $\beta$-like cells more efficiently compared to the GP2negative fraction $(24,25)$. In addition, depletion of pluripotent cells from differentiated PSC cultures using genetic, chemical and antibody-based approaches has been investigated as promising approach to increase safety of PSC differentiated cells. For instance, Lee and coworkers discovered that chemical inhibitors of survivin (like quercetin or YM155) induced selective and complete cell death of undifferentiated hPSC (26), while Ben-David and colleagues using an highthroughput screen of over 52,000 small molecules identified an inhibitor of stearoyl-coA desaturase (SCD1) able to selectively eliminate hPSC (27). Over the latest years, photodynamic approach is getting a foothold. Interestingly, it was demonstrated that CDy1, a PSC-selective fluorescent probe, led to mitochondrial ROS production upon visible light irradiation and consequent selective PSC death, avoiding teratoma formation (28). An additional approach is the introduction of a suicide gene under NANOG promoter control leading to selective removal of undifferentiated PSCs from differentiated cell culture after drug treatment (29). Moreover, also the introduction of an innovative inducible caspase- 9 suicide gene in hPSC able to induced 94-99\% cell death after chemical inducer of dimerization (CID) treatment has been tested (30).

3. Development of macro-encapsulation devices able to protect cells from immune attack and allow retrieval in case of undesirable tumor. During the past decade, much effort has been directed to the clinical application of therapeutic cells encapsulation in biocompatible, permselective and safe macrodevices (31). Beta-O2 developed an alginate scaffold containing allogenic human islets supplied with oxygen by daily injection, known as $\beta$ Air device (32). The first T1D patient was implanted in 2012 in the absence of immunosuppression and

$$
\text { http://www.endocrineconnections.org }
$$

showed persistent graft function with preservation of islets morphology although only moderate improvements on clinical disease were observed (33). Two years later, Beta-O2 Technologies started a clinical trial (NCT02064309) to evaluate safety and efficacy of human islet encapsulation into $\beta$ Air device in T1D patients. Moreover, also the ability of $\beta$ Air technology to sustain hESC differentiation into mature endocrine cells in rodent was demonstrated (34). Recently, Beta-O2 bioartificial pancreas device was used as preclinical model for xenogenic islet transplantation. Authors reported enduring graft function, resulting in regulated insulin secretion, without generation of immune system attack (35). The main limitations of this device consist in the partial function of encapsulated islets and in the procedure of daily exogenous oxygen refilling, which requires a knowledgeable and compliant patient.

As previously mentioned, in 2014, ViaCyte launched the first phase I/II human clinical trial evaluating efficiency of Encaptra Device combined with PEC-01 cells in T1D patients. Additionally, in 2017, U.S. Food and Drug Administration (FDA) has allowed clinical testing for ViaCyte's PEC-Direct product, a new open Encaptra Device allowing direct vascularization of PEC-01 cells. At the 5th Annual European Advanced Therapies Investor day (http://eu.arminvestorday.com), ViaCyte presented some data of the ongoing clinical trial reporting good tissue integration and vascularization of the system in two patients. Another device received approval from the FDA for phase I/II clinical study in T1D patients in US: the Cell Pouch System is a medical biocompatible macrodevice designed to be implanted in the subcutaneous site, forming highly vascularized tissue chambers few weeks prior to transplantation of islets (36). Ongoing clinical trials from ViaCyte are summarized in Table 1.

\section{$\beta$ cells from direct differentiation}

As discussed, clinical application of PSCs is not without roadblocks due to shortage of genetic understanding of pancreatic embryogenesis leading to partial $\beta$ cell differentiation efficiency, risk of tumor formation caused by residual undifferentiated cells and the eventuality of cell death after transplantation. Thus, several research groups focused on direct reprogramming (transdifferentiation) of non- $\beta$ adult cells, such as pancreatic exocrine cells, liver cells and stomach cells, into insulin-producing cells, 
Table 1 Clinical studies of ViaCyte testing safety, tolerability and efficacy of ESC-derived pancreatic progenitor cells (PEC-01 cells) encapsulated into a macrodevice (Encaptra cell delivery system).

\begin{tabular}{|c|c|c|c|c|c|c|}
\hline $\begin{array}{l}\text { ClinicalTrials.gov } \\
\text { identifier }\end{array}$ & Name & Cell product & $\begin{array}{l}\text { Study } \\
\text { type }\end{array}$ & Study location & Conditions & Status \\
\hline NCT02239354 & $\begin{array}{l}\text { A safety, tolerability } \\
\text { and efficacy study } \\
\text { of VC-01 } \\
\text { combination } \\
\text { product in subjects } \\
\text { with type } 1 \text { diabetes } \\
\text { mellitus }\end{array}$ & $\begin{array}{l}\text { VC-01 } \\
\text { combination } \\
\text { product } \\
\text { (PEC-Encap) }\end{array}$ & Phase $1 / 2$ & $\begin{array}{l}\text { University of } \\
\text { California at San } \\
\text { Diego, United } \\
\text { States } \\
\text { University of } \\
\text { Alberta Hospital, } \\
\text { Canada }\end{array}$ & $\begin{array}{l}\text { Type } 1 \text { diabetes mellitus, } \\
\text { no immunosuppression }\end{array}$ & $\begin{array}{r}\text { Active, not } \\
\text { recruiting }\end{array}$ \\
\hline NCT03162926 & $\begin{array}{l}\text { A safety and } \\
\text { tolerability study of } \\
\text { VC- } 02 \text { combination } \\
\text { product in subjects } \\
\text { with type } 1 \text { diabetes } \\
\text { mellitus }\end{array}$ & $\begin{array}{l}\text { VC-02 } \\
\text { combination } \\
\text { product } \\
\text { (PEC-Direct) }\end{array}$ & Phase 1 & $\begin{array}{l}\text { University of } \\
\text { Alberta, } \\
\text { Edmonton, } \\
\text { Canada }\end{array}$ & $\begin{array}{l}\text { Type } 1 \text { diabetes mellitus, } \\
\text { with } \\
\text { immunosuppression }\end{array}$ & $\begin{array}{r}\text { Active, not } \\
\text { recruiting }\end{array}$ \\
\hline NCT03163511 & $\begin{array}{l}\text { A safety, tolerability } \\
\text { and efficacy study } \\
\text { of VC-02 combina- } \\
\text { tion product in } \\
\text { subjects with type } 1 \\
\text { diabetes mellitus } \\
\text { and hypoglycemia } \\
\text { unawareness }\end{array}$ & $\begin{array}{l}\text { VC-02 combina- } \\
\text { tion product } \\
\text { (PEC-Direct) }\end{array}$ & Phase 1/2 & $\begin{array}{l}\text { University of } \\
\text { California, San } \\
\text { Diego, United } \\
\text { States } \\
\text { University of } \\
\text { Minnesota, } \\
\text { Minneapolis, } \\
\text { United States } \\
\text { Ohio State } \\
\text { University, } \\
\text { Columbus, } \\
\text { United States } \\
\text { University of } \\
\text { Alberta, } \\
\text { Edmonton, } \\
\text { Canada } \\
\text { University of } \\
\text { British Columbia, } \\
\text { Vancouver, } \\
\text { Canada }\end{array}$ & $\begin{array}{l}\text { Type } 1 \text { diabetes mellitus } \\
\text { with hypoglycemia, } \\
\text { with immunosuppres- } \\
\text { sion }\end{array}$ & $\begin{array}{l}\text { Active, } \\
\text { recruiting }\end{array}$ \\
\hline
\end{tabular}

skipping the pluripotent stage $(37,38,39)$. Common endodermic origin of these cell types suggests that they could be converted into insulin-producing $\beta$ cells.

\section{Alpha-to- $\beta$}

Under different diabetic stress conditions, glucagonproducing $\alpha$ cells are important to maintain $\beta$ cell health and function through GLP-1 secretion $(40,41)$ suggesting an $\alpha$-cell-mediated adaptive response to $\beta$-cell stress and injury. Collombat and colleagues demonstrated that overexpression of ectopic Paired Box 4 (PAX4) (42) or selective inhibition of Aristaless-Related Homeobox $(A R X)(43)$ are able to determine an $\alpha$ cells conversion into functional $\beta$ cells and restore normoglycemia in STZinduced diabetic mice. Moreover, Herrera's group showed that a diphtheria toxin-mediated $\beta$-cell removal (>99\%) in mice led to an $\alpha$ cells expansion and a spontaneous reprogramming in $\beta$ cells (44). Thus, over the latest years, the possibility to induce direct differentiation of glucagon-producing $\alpha$ cells into insulin-producing $\beta$ cells have captured attention of diabetes researchers as interesting therapeutic approach for restoring $\beta$ cell function in T1D patients. Recently, Collombat's group provided in vitro and ex vivo experimental evidences that long-term $\gamma$-aminobutyric acid (GABA) administration, a food supplement, can induce human $\alpha$-cell-mediated $\beta$-like cell neogenesis opening the way for clinical trials with GABA compounds (45). Additionally, Li and colleagues corroborated GABA data identifying a small antimalarial molecule, named Artemisinins, involved in ARX repression and consequent increased GABA signaling. This mechanism resulted in decreased glucagon secretion by $\alpha$ cells and their differentiation into insulin-producing cells (46). However, in the same http://www.endocrineconnections.org https://doi.org/10.1530/EC-18-0012 (c) 2018 The authors Published by Bioscientifica Ltd
This work is licensed under a Creative Commons Attribution-NonCommercial-NoDerivatives 4.0 International License. 
year, another group confirmed the inhibition of $A R X$ after Artemether treatment (an Artemisinins derivative) but no $\alpha$ to $\beta$ conversion in mouse primary islets (47). These controversial findings generated a state of uncertainty regarding GABA transdifferentiation effects. Very recently, the transcription factors PDX1 and MAF-A were delivered in vivo with adeno-associated virus to the mouse pancreas through the pancreatic duct to reprogram $\alpha$ cells into functional $\beta$ cells. Blood glucose levels normalized in both chemically induced diabetic mice and autoimmune nonobese diabetic (NOD) mice. This gene therapy strategy also induced $\alpha$ to $\beta$ cell conversion in toxin-treated human islets, which restored blood glucose levels in NOD/SCID mice upon transplantation (48).

\section{Exocrine-to- $\beta$}

Exocrine pancreas, consisting of acinar and ductal cells, makes up approximately 98 percent of the adult organ (49), therefore, much attention was focused on the possibility to generate new $\beta$ cells from these cell types.

\section{Acinar cells}

Melton's group provided evidence about acinar-to- $\beta$ transdifferentiation inducing in vivo overexpression of three key $\beta$-cell transcription factors PDX1, NGN3 and $M A F A$ in combination with GFP in mice. By $72 \mathrm{~h}$ after viral infection in $\mathrm{Rag}^{-/-}$non-diabetic animals, new GFP-insulin-positive cells were detected. After 10 days, GFP-positive cells presented key features of bona fide $\beta$ cells. Furthermore, overexpression of transcription factors in STZ-induced diabetic mice led to a significant decrease of hyperglycemia, although did not reverse diabetes (50). Lately, they confirmed the survival and function of lineage-reprogrammed cells in vivo up to 1 year (51). Similarly, Docherty's group described a new acinar-to- $\beta$ reprogramming protocol, starting from in vitro cultured primary human exocrine cells. Epithelialto-mesenchymal transition (EMT) inhibition maintained acinar exocrine phenotype in culture and overexpression of the four pancreatic transcription factors PDX1, NGN3, PAX4 and MAFA, with a combination of several growth factors, generated functional glucose-responding insulinproducing cells, that were able to normalize glycemia in STZ-induced diabetic immunodeficient mice (52). In 2016, the same group confirmed the possibility to generate functional clinically relevant $\beta$ cells from human exocrine pancreas, adding ARX knockdown to the strategy (53).
In the latest years, a Belgian group demonstrated that forcing expression of mitogen-activated protein kinase (MAPK) and signal transducer and activator of transcription 3 (STAT3) in human exocrine cells cultured in 3D structures induces NGN3 expression, leading to an acinoinsular functional reprogramming (54). Obviously, these approaches present clinical limitation due to the use of viral vectors. For this reason, several researchers focused on pharmacological induction of transdifferentiation. For instance, epidermal growth factor (EGF), nicotinamide, leukemia inhibitory factor (LIF) or ciliary neurotrophic factor (CNTF) combination reprogrammed rat acinar cells into insulin-producing $\beta$ cells in vitro able to restore normoglycemia in diabetic mice. Molecular study reported the involvement of CNTF in STAT3 signaling pathway activation leading to reactivation of NGN3 expression in adult acinar cells forcing differentiation into $\beta$ cells $(55,56)$. Recently, a Japanese group showed that inducing ectopic expression of glucagon-like peptide-1 receptor (GLP1R) combined with gastrin and exendin- 4 also, synergistically promoted $\beta$ cell reprogramming of acinar cells (57).

\section{Duct cells}

Reprogramming of ductal cells into $\beta$ cells is one of the most controversial issue in the field. In the last two decades, several papers showed budding of $\beta$ cells from duct cells speculating that pancreatic duct could be a potential stem cell niche for insulin-producing cells (58). In 2008, Heimberg's group reported that after pancreatic duct ligation (PDL) in mice, $\beta$ cell progenitors located in the duct could re-express NGN3 and differentiate into glucose-responsive $\beta$ cells (59). In the same year, another group corroborated these findings showing, through the forced expression of ductal marker carbonic anhydrase II (CAII), that duct cells acted as $\beta$ cell progenitors after birth or PDL, leading to the formation of new islets (60). Intriguingly, Corritore, in collaboration with our group, forced purified human ductal cells to undergo an EMT and proliferate. After expansion, it was possible to differentiate, with a protocol mimicking pancreatic development, duct-derived cells into $\beta$-cells. These cells expressed $\beta$ cell markers and were able to secrete insulin, but not in a glucose-dependent manner (61). More recently, Zhang and colleagues provided evidence that long-term administration of gastrin and EGFs in vivo in diabetic mice, resulted in ductal cell transdifferentiation into new $\beta$ cells and consequent diabetes reversion (62). However, these findings are still subject of dispute since several studies suggested a non-ductal contribution to endocrine cell 
regeneration $(63,64,65,66)$. These conflicting findings generate doubts regarding the importance of ductal cells in $\beta$ cell regeneration.

\section{Liver-to- $\beta$}

Pancreas, gastrointestinal tract and liver have the same embryonic origin deriving from primitive foregut endoderm; thus, a transdifferentiation between them is conceivable.

Liver is the largest organ in the body and, unlike $\beta$ cells, is able to regenerate and proliferate efficiently. In addition, liver shares with pancreas the glucose responsiveness. Thus, hepatic cells represent a good therapeutic potential candidate for $\beta$ cell generation $(67,68)$. Ferber and colleagues were the first researchers demonstrating that in vivo adenoviral-mediated ectopic expression of PDX1 in liver generated increase of silent endogenous INS gene expression. Moreover, insulin levels derived from hepatic-PDX1 overexpression ameliorated STZ-induced diabetes $(69,70,71)$. From 2000 onwards, several authors have provided evidence of liver-to- $\beta$ transdifferentiation through hepatic ectopic expression of pancreatic transcription factors, such as PDX1, NGN3, MAFA and NKX6.1, leading to a partial $\beta$ cell phenotype and reversion of hyperglycemia in chemical-induced diabetic mice, indicating this approach as a promising cell-based replacement therapy for diabetes $(72,73,74,75)$.

\section{Gastrointestinal-to- $\beta$}

Gastrointestinal tissues, composed by stomach and intestine, harbor NGN3-expressing progenitor cells able to become hormone-producing cells (76). Over the last decade, several evidences have demonstrated that gastrointestinal cells can be reprogrammed into insulin-producing cells through expression or deletion of some transcription factors. Recent studies showed that intestinal cells gave rise to functional $\beta$-like cells by endocrine-specific ablation of Forkhead box protein $\mathrm{O} 1$ (FOXO1) transcription factor $(77,78)$. In 2014, Chen and coworkers reported a rapid conversion of intestinal crypt cells into endocrine cells through ectopic expression of PDX1, MAFA and NGN3 factors. They observed formation of 'neoislets' below the crypt base that were able to secrete insulin in a glucose-dependent manner and ameliorate hyperglycemia in diabetic mice (79). Recently, Zhou's group showed that antral enteroendocrine cells also were able to generate functional insulin-positive cells through adenoviral expression of the same transcription factors. This approach resulted in higher transdifferentiation efficiency compared to the previously mentioned intestinal enteroendocrine cell reprogramming. Intriguingly, authors assembled in vitro reprogrammed antral stomach cells into bio-organoids and observed hyperglycemia reversion in diabetic mice. This novel approach shed light to engineered stomach tissue as renewable functional $\beta$ cell source (37).

\section{Last advances in the field: genome editing}

Finally, advances in genome editing technologies have revolutionized the field. In particular, discovery of the bacterial immune system CRISPR/Cas9 has led to the development of tools for rapid and efficient RNA-based, sequence-specific genome editing (80). Furthermore, novel modifications to the CRISPR/Cas9 system have provided opportunities for regulating gene expression and for creating epigenetic alterations, without creating DNA breaks (81). Very recently, a new system for in vivo activation of endogenous target genes through transepigenetic remodeling was reported: this system relies on recruitment of Cas9 and transcriptional activation complexes to target loci by modified single guide RNAs, and it was used to transdifferentiate liver cells into insulin-positive cells, acting on PDX1 levels in mice. Besides, when mice, rendered diabetic with streptozotocin (STZ) treatment, were treated with the system for endogenous insulin gene activation, they partially rescued hyperglycemia (82).

\section{Last advances in the field: chimeric organs}

The availability of PSCs boosted the possibility of producing human organs in animals. The main strategy to obtain chimeric animals was based on blastocyst complementation: mouse ESC injected into a blastocyst were shown able to contribute to embryo development (83). When blastocyst and ESC had a different genetic background, the outcome was a chimeric mouse with cells of both origins in its organs. Genetically modified PSCs injected in blastocyst are the basis of the production of transgenic mice. More recently, blastocyst complementation was used to generate interspecies chimeric animals. The hypothesis was that if PSC were 
injected into blastocysts obtained from mutant mice in which the development of a certain organ was precluded by genetic manipulation, thereby leaving a niche for organ development, the PSC-derived cells would developmentally compensate for the defect and form the missing organ. At first, rat pancreas was generated by injection of PSC into pancreas-deficient $P D X 1^{-/-}$ mouse blastocysts (84), then kidney was generated using $S A L L 1^{-/-}$mouse blastocysts (85). The demonstration that a rat organ can be produced in a mouse suggested that it could be possible to produce xenogeneic organs in various animal species, including production of human organs. This could have a tremendous impact in the field of regenerative medicine, since the shortage of donor organs is a major obstacle to the expansion of whole organ replacement therapies. For production of human organs, human iPSC would be injected into blastocysts obtained from carrier animals genetically modified in order to block the development of a given organ. Thus, only human cells would contribute to the development of that organ (86). Importantly, also in this case, the use of autologous iPSC could allow the production of autologous human organs and therefore ideally reduce the long-term need for immunosuppressive drugs after transplantation. These chimeric animals would be raised until the human organ reached the required size and then they would be killed for transplantation. Pigs are the most attractive animals to bear human organs for various reasons: (i) the size of their organs is similar, (ii) their metabolism (for instance, diet and temperature) is close to the human one, (iii) there is a significant experience regarding pig cell transplantation in humans within the context of xenotransplantation trials, which facilitates the identification of hazards and barriers, such as infectious and immunological risks, to be overcome for transplantation in humans of human cells or organs that have been grown in a pig (87).

Some preliminary experiments have already been performed, such as injection of human ESC into a mouse blastocyst (88), but the results obtained suggest that this process is rather inefficient (89). At the beginning of 2017, two seminal papers were published regarding the creation of chimeras using pluripotent human stem cells obtained from iPSC and blastocysts of pigs and bovine (90, 91). In Belmonte's paper PDX1 gene, fundamental for pancreas development, was initially suppressed by CRISPR-Cas9-mediated gene editing in the mouse zygote creating a blastocyst not able to give life to adult mice with pancreas, then rat stem cells were inserted into the blastocyst and the resulting embryo gave rise to adult mice with pancreas composed exclusively of rat cells. The same type of approach was also successfully applied with other targets such as NKX2.5 (relevant for cardiac development) and PAX6 (relevant for eye development) demonstrating that the approach can be extended in a systematic way. Finally, the authors applied the same strategy using human stem cells in pig or bovine blastocysts. Although with less efficiency than the rat-mouse model, the possibility of obtaining chimeric human embryos was demonstrated (91). In Nakauchi's paper, mouse PSCs were injected into PDX1-deficient rat blastocysts, and ratsized pancreas composed of mouse-PSC-derived cells were generated. Islets isolated from the mouse-rat chimeric pancreas were transplanted into diabetic mice and were able to normalize and maintain host blood glucose levels for over 1 year in the absence of immunosuppression (90). Finally, a new study reported the possibility to disable pancreas development in sheep through CRISPR/Cas9 microinjection in oocytes, widening the possibility to create human-animal chimeras for human pancreas generation (92).

These works constitute a turning point in the field of regenerative medicine, opening up unimaginable horizons, but also impose big challenges. From the biotechnological point of view, the proof of principle has been developed but efficiency of human-pig chimeras is low and the insertion of human cells into the pig embryo has shown important limitations. The field of human chimeras also raises strong ethical issues. The main ethical dilemmas are whether the chimera can be killed in order to obtain organs and if a man-animal chimera has a different ethical identity than the animal one. Finally, there is obviously an enormous ethical concern in the case of any human germ cell contribution. Overall, this is an exciting but extremely delicate field of research.

\section{Future perspectives}

In conclusion, $\beta$ cells derived from PSC currently represent the most concrete new source for cell replacement therapy in T1D. The results of ongoing clinical trials will provide valuable information and will tell us if this is the strategy of the future. Looking ahead, the field of cell therapy with iPSC is facing a turning point, where new technologies and synergies can transform a type of approach limited to few patients into a therapeutic option for large groups of patients. This evolution is closely linked to the scale up of cell reprogramming, differentiation and banking, which is necessarily connected to the industrialization of processes. In the meantime, the huge progresses made by 
technologies of ex vivo and in vivo gene editing allowed increasingly efficient transformation of somatic cells into $\beta$ cells and the creation of new chimeric organs. These approaches have the potential to innovate the field, but issues of safety and ethics will need to be considered.

\section{Declaration of interest}

The authors declare that there is no conflict of interest that could be perceived as prejudicing the impartiality of this review.

\section{Funding}

The work of the authors is currently supported by the European Commission (H2020 grant 681070), Fondazione Diabete Ricerca ONLUS (Società Italiana di Diabetologia-SID) and Eli Lilly Italia (grant 'Sostegno alla ricerca sul diabete $2017^{\prime}$ ).

\section{References}

1 Atkinson MA, Bluestone JA, Eisenbarth GS, Hebrok M, Herold KC, Accili D, Pietropaolo M, Arvan PR, Von Herrath M, Markel DS, et al. How does type 1 diabetes develop? The notion of homicide or -cell suicide revisited. Diabetes 201160 1370-1379. (https://doi. org/10.2337/db10-1797)

2 Atkinson MA, Eisenbarth GS \& Michels AW. Type 1 diabetes. Lancet 2014383 69-82. (https://doi.org/10.1016/S0140-6736(13)60591-7)

3 Van Belle TL, Coppieters KT \& von Herrath MG. Type 1 diabetes: etiology, immunology, and therapeutic strategies. Physiological Reviews 201191 79-118. (https://doi.org/10.1152/ physrev.00003.2010)

4 Maffi P \& Secchi A. Clinical results of islet transplantation. Pharmacological Research 201598 86-91. (https://doi.org/10.1016/j. phrs.2015.04.010)

5 Sordi V, Pellegrini S, Krampera M, Marchetti P, Pessina A, Ciardelli G, Fadini G, Pintus C, Pantè G \& Piemonti L. Stem cells to restore insulin production and cure diabetes. Nutrition, Metabolism and Cardiovascular Diseases 201627 583-600. (https://doi.org/10.1016/j. numecd.2017.02.004)

6 Lysy PA, Weir GC \& Bonner-Weir S. Concise review: pancreas regeneration: recent advances and perspectives. Stem Cells Translational Medicine 20121 150-159. (https://doi.org/10.5966/ sctm.2011-0025)

7 D'Amour KA, Bang AG, Eliazer S, Kelly OG, Agulnick AD, Smart NG, Moorman MA, Kroon E, Carpenter MK \& Baetge EE. Production of pancreatic hormone-expressing endocrine cells from human embryonic stem cells. Nature Biotechnology 200624 1392-1401. (https://doi.org/10.1038/nbt1259)

8 Kroon E, Martinson LA, Kadoya K, Bang AG, Kelly OG, Eliazer S, Young H, Richardson M, Smart NG, Cunningham J, et al. Pancreatic endoderm derived from human embryonic stem cells generates glucose-responsive insulin-secreting cells in vivo. Nature Biotechnology 200826 443-452. (https://doi.org/10.1038/nbt1393)

9 Rezania A, Bruin JE, Arora P, Rubin A, Batushansky I, Asadi A, O'Dwyer S, Quiskamp N, Mojibian M, Albrecht T,et al. Reversal of diabetes with insulin-producing cells derived in vitro from human pluripotent stem cells. Nature Biotechnology 201432 1121-1133. (https://doi.org/10.1038/nbt.3033)

10 Pagliuca FW, Millman JR, Gürtler M, Segel M, Van Dervort A, Ryu JH, Peterson QP, Greiner D \& Melton DA. Generation of functional human pancreatic $\beta$ cells in vitro. Cell 2014159 428-439. (https:// doi.org/10.1016/j.cell.2014.09.040)
11 Takahashi K, Tanabe K, Ohnuki M, Narita M, Ichisaka T, Tomoda K \& Yamanaka S. Induction of pluripotent stem cells from adult human fibroblasts by defined factors. Cell 2007131 861-872. (https://doi. org/10.1016/j.cell.2007.11.019)

12 Millman JR, Xie C, Dervort Van A, Gürtler M, Pagliuca FW \& Melton DA. Generation of stem cell-derived b-cells from patients with type 1 diabetes. Nature Communications 20167 11463. (https:// doi.org/10.1038/ncomms11463)

13 Kondo Y, Toyoda T, Ito R, Funato M, Hosokawa Y, Matsui S, Sudo T, Nakamura M, Okada C, Zhuang X, et al. Identification of a small molecule that facilitates the differentiation of human iPSCs/ESCs and mouse embryonic pancreatic explants into pancreatic endocrine cells. Diabetologia 201760 1454-1466. (https://doi.org/10.1007/s00125-017-4302-7)

14 Yabe SG, Fukuda S, Takeda F, Nashiro K, Shimoda M \& Okochi H. Efficient generation of functional pancreatic $\beta$-cells from human induced pluripotent stem cells. Journal of Diabetes 2017 9168-179. (https://doi.org/10.1111/1753-0407.12400)

15 Maehr R, Chen S, Snitow M, Ludwig T, Yagasaki L, Goland R, Leibel RL \& Melton DA. Generation of pluripotent stem cells from patients with type 1 diabetes. PNAS 2009106 15768-15773. (https:// doi.org/10.1073/pnas.0906894106)

16 Wakayama S, Jakt ML, Suzuki M, Araki R, Hikichi T, Kishigami S, Ohta H, Van Thuan N, Mizutani E, Sakaide Y, et al. Equivalency of nuclear transfer-derived embryonic stem cells to those derived from fertilized mouse blastocysts. Stem Cells 200624 2023-2033. (https:// doi.org/10.1634/stemcells.2005-0537)

17 Yamada M, Johannesson B, Sagi I, Burnett LC, Kort DH, Prosser RW, Paull D, Nestor MW, Freeby M, Greenberg E, et al. Human oocytes reprogram adult somatic nuclei of a type 1 diabetic to diploid pluripotent stem cells. Nature 2014510 533-536. (https://doi. org/10.1038/nature13287)

18 Sui L, Danzl N, Campbell SR, Viola R, Williams D, Xing Y, Wang Y, Phillips N, Poffenberger G, Johannesson B, et al. $\beta$-Cell replacement in mice using human type 1 diabetes nuclear transfer embryonic stem cells. Diabetes 201867 26-35. (https://doi.org/10.2337/db17-0120)

19 Rezania A, Bruin JE, Riedel MJ, Mojibian M, Asadi A, Xu J, Gauvin R, Narayan K, Karanu F, O’Neil JJ, et al. Maturation of human embryonic stem cell-derived pancreatic progenitors into functional islets capable of treating pre-existing diabetes in mice. Diabetes 2012 61 2016-2029. (https://doi.org/10.2337/db11-1711)

$20 \mathrm{Hu} \mathrm{K}$. All roads lead to induced pluripotent stem cells: the technologies of iPSC generation. Stem Cells and Development 201423 1285-1300. (https://doi.org/10.1089/scd.2013.0620)

21 Kelly OG, Chan MY, Martinson LA, Kadoya K, Ostertag TM, Ross KG, Richardson M, Carpenter MK, D'Amour KA, Kroon E, et al. Cellsurface markers for the isolation of pancreatic cell types derived from human embryonic stem cells. Nature Biotechnology 201129 750-756. (https://doi.org/10.1038/nbt.1931)

22 Jiang W, Sui X, Zhang D, Liu M, Ding M, Shi Y \& Deng H. CD24: a novel surface marker for PDX1-positive pancreatic progenitors derived from human embryonic stem cells. Stem Cells 201129 609-617. (https://doi.org/10.1002/stem.608)

23 Hald J, Galbo T, Rescan C, Radzikowski L, Sprinkel AE, Heimberg H, Ahnfelt-Rønne J, Jensen J, Scharfmann R, Gradwohl G, et al. Pancreatic islet and progenitor cell surface markers with cell sorting potential. Diabetologia 201255 154-165. (https://doi.org/10.1007/ s00125-011-2295-1)

24 Ameri J, Borup R, Prawiro C, Ramond C, Schachter KA, Scharfmann R $\&$ Semb H. Efficient generation of glucose-responsive beta cells from isolated GP2 + human pancreatic progenitors. Cell Reports 201719 36-49. (https://doi.org/10.1016/j.celrep.2017.03.032)

25 Cogger KF, Sinha A, Sarangi F, McGaugh EC, Saunders D, Dorrell C, Mejia-Guerrero S, Aghazadeh Y, Rourke JL, Screaton RA, et al. Glycoprotein 2 is a specific cell surface marker of human pancreatic progenitors. Nature Communications 20178 331. (https://doi. org/10.1038/s41467-017-00561-0)

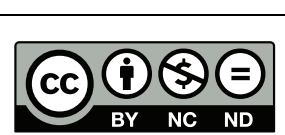

This work is licensed under a Creative Commons Attribution-NonCommercial-NoDerivatives 4.0 International License. 
26 Lee M-O, Moon SH, Jeong H-C, Yi JY, Lee TH, Shim SH, Rhee YH, Lee SH, Oh SJ, Lee MY, et al. Inhibition of pluripotent stem cellderived teratoma formation by small molecules. PNAS $2013 \mathbf{1 1 0}$ E3281-E3290. (https://doi.org/10.1073/pnas.1303669110)

27 Ben-David U, Gan Q-F, Golan-Lev T, Arora P, Yanuka O, Oren YS Leikin-Frenkel A, Graf M, Garippa R, Boehringer M, et al. Selective elimination of human pluripotent stem cells by an oleate synthesis inhibitor discovered in a high-throughput screen. Cell Stem Cell 2013 12 167-179. (https://doi.org/10.1016/j.stem.2012.11.015)

28 Cho S-J, Kim S-Y, Park S-J, Song N, Kwon H-Y, Kang N-Y, Moon SH, Chang Y-T \& Cha H-J. Photodynamic approach for teratomafree pluripotent stem cell therapy using CDy1 and visible light. ACS Central Science 20162 604-607. (https://doi.org/10.1021/ acscentsci.6b00099)

29 Chen F, Cai B, Gao Y, Yuan X, Cheng F, Wang T, Jiang M, Zhou Y, Lahn BT, Li W, et al. Suicide gene-mediated ablation of tumorinitiating mouse pluripotent stem cells. Biomaterials $2013 \mathbf{3 4}$ 1701-1711. (https://doi.org/10.1016/j.biomaterials.2012.11.018)

30 Yagyu S, Hoyos V, Del Bufalo F \& Brenner MK. An inducible caspase-9 suicide gene to improve the safety of therapy using human induced pluripotent stem cells. Molecular Therapy 201523 1475-1485. (https://doi.org/10.1038/mt.2015.100)

31 Scharp DW \& Marchetti P. Encapsulated islets for diabetes therapy: history, current progress, and critical issues requiring solution. Advanced Drug Delivery Reviews 2014 67-68 35-73. (https://doi. org/10.1016/j.addr.2013.07.018)

32 Ludwig B, Zimerman B, Steffen A, Yavriants K, Azarov D, Reichel A, Vardi P, German T, Shabtay N, Rotem A, et al. A novel device for islet transplantation providing immune protection and oxygen supply. Hormone and Metabolic Research 201042 918-922. (https://doi. org/10.1055/s-0030-1267916)

33 Ludwig B, Reichel A, Steffen A, Zimerman B, Schally AV, Block NL, Colton CK, Ludwig S, Kersting S, Bonifacio E, et al. Transplantation of human islets without immunosuppression. PNAS $2013 \mathbf{1 1 0}$ 19054-19058. (https://doi.org/10.1073/pnas.1317561110)

34 Bukys MA, Bakos B, Afelik S, Zimmerman B, Barbaro B, Lin DL, Vaca P, Goldman T, Rotem A, Damaser M, et al. Xeno-transplantation of macro-encapsulated human islet and pluripotent stem cell-derived pancreatic progenitors in absence of immunosuppression. Diabetes 20142 1-10. (https://doi.org/10.19104/jorm.2017.109)

35 Ludwig B, Ludwig S, Steffen A, Knauf Y, Zimerman B, Heinke S, Lehmann S, Schubert U, Schmid J, Bleyer M, et al. Favorable outcome of experimental islet xenotransplantation without immunosuppression in a nonhuman primate model of diabetes. PNAS 2017114 11745-11750. (https://doi.org/10.1073/ pnas.1708420114)

36 Pepper AR, Pawlick R, Gala-Lopez B, MacGillivary A, Mazzuca DM, White DJG, Toleikis PM \& Shapiro AMJ. Diabetes is reversed in a murine model by marginal mass syngeneic islet transplantation using a subcutaneous cell pouch device. Transplantation 201599 2294-2300. (https://doi.org/10.1097/TP.0000000000000864)

37 Ariyachet C, Tovaglieri A, Xiang G, Lu J, Shah MS, Richmond CA, Verbeke C, Melton DA, Stanger BZ, Mooney D, et al. Reprogrammed stomach tissue as a renewable source of functional $\beta$ cells for blood glucose regulation. Cell Stem Cell 201618 410-421. (https://doi. org/10.1016/j.stem.2016.01.003)

38 Sisakhtnezhad S \& Matin MM. Transdifferentiation: a cell and molecular reprogramming process. Cell and Tissue Research 2012348 379-396. (https://doi.org/10.1007/s00441-012-1403-y)

39 Lysy PA, Weir GC \& Bonner-Weir S. Making $\beta$ cells from adult cells within the pancreas. Current Diabetes Reports 201313 695-703. (https://doi.org/10.1007/s11892-013-0400-1)

40 Kilimnik G, Kim A, Steiner DF, Friedman TC \& Hara M. Intraislet production of GLP-1 by activation of prohormone convertase $1 / 3$ in pancreatic $\alpha$-cells in mouse models of $\beta$-cell regeneration. Islets 2010 2 149-155. (https://doi.org/10.4161/isl.2.3.11396)
41 Liu Z, Stanojevic V, Avadhani S, Yano T \& Habener JF. Stromal cell-derived factor-1 (SDF-1)/chemokine (C-X-C motif) receptor 4 (CXCR4) axis activation induces intra-islet glucagon-like peptide-1 (GLP-1) production and enhances beta cell survival. Diabetologia 201154 2067-2076. (https://doi.org/10.1007/s00125-011-2181-x)

42 Collombat P, Xu X, Ravassard P, Sosa-Pineda B, Dussaud S, Billestrup N, Madsen OD, Serup P, Heimberg H \& Mansouri A. The ectopic expression of Pax4 in the mouse pancreas converts progenitor cells into alpha and subsequently beta cells. Cell 2009138 449-462. (https://doi.org/10.1016/j.cell.2009.05.035)

43 Courtney M, Gjernes E, Druelle N, Ravaud C, Vieira A, BenOthman N, Pfeifer A, Avolio F, Leuckx G, Lacas-Gervais S, et al. The inactivation of Arx in pancreatic $\alpha$-cells triggers their neogenesis and conversion into functional $\beta$-like cells. PLoS Genetics 20139 e1003934. (https://doi.org/10.1371/journal.pgen.1003934)

44 Thorel F, Népote V, Avril I, Kohno K, Desgraz R, Chera S \& Herrera PL. Conversion of adult pancreatic alpha-cells to beta-cells after extreme beta-cell loss. Nature 2010464 1149-1154. (https://doi. org/10.1038/nature08894)

45 Ben-Othman N, Vieira A, Courtney M, Record F, Gjernes E, Avolio F, Hadzic B, Druelle N, Napolitano T, Navarro-Sanz S, et al. Long-term GABA administration induces alpha cell-mediated beta-like cell neogenesis. Cell 2017168 73.e11-85.e11. (https://doi.org/10.1016/j.cell.2016.11.002)

46 Li J, Casteels T, Frogne T, Ingvorsen C, Honoré C, Courtney M, Huber KVM, Schmitner N, Kimmel RA, Romanov RA, et al. Artemisinins target GABA a receptor signaling and impair $\alpha$ cell identity. Cell 2017168 86.e15-100.e15. (https://doi.org/10.1016/j. cell.2016.11.010)

47 Van der Meulen T, Lee S, Noordeloos E, Donaldson CJ, Adams MW, Noguchi GM, Mawla AM \& Huising MO. Artemether does not turn $\alpha$ cells into $\beta$ cells. Cell Metabolism 201727 218.e4-225.e4. (https://doi. org/10.1016/j.cmet.2017.10.002)

48 Xiao X, Guo P, Shiota C, Zhang T, Coudriet GM, Fischbach S, Prasadan K, Fusco J, Ramachandran S, Witkowski P, et al. Endogenous reprogramming of alpha cells into beta cells, induced by viral gene therapy, reverses autoimmune diabetes. Cell Stem Cell 20182278. e4-90.e4. (https://doi.org/10.1016/j.stem.2017.11.020)

49 Guney MA \& Gannon M. Pancreas cell fate. Birth Defects Research, Part C: Embryo Today, Reviews 200987 232-248. (https://doi. org/10.1002/bdrc.20156)

50 Zhou Q, Brown J, Kanarek A, Rajagopal J \& Melton DA. In vivo reprogramming of adult pancreatic exocrine cells to $\beta$-cells. Nature 2008455 627-632. (https://doi.org/10.1038/nature07314)

51 Li W, Cavelti-Weder C, Zhang Y, Clement K, Donovan S, Gonzalez G, Zhu J, Stemann M, Xu K, Hashimoto T, et al. Long-term persistence and development of induced pancreatic beta cells generated by lineage conversion of acinar cells. Nature Biotechnology 201432 1223-1230. (https://doi.org/10.1038/nbt.3082)

52 Lima MJ, Muir KR, Docherty HM, Drummond R, McGowan NW, Forbes S, Heremans Y, Houbracken I, Ross JA, Forbes SJ, et al. Suppression of epithelial-to-mesenchymal transitioning enhances ex vivo reprogramming of human exocrine pancreatic tissue toward functional insulin-producing $\beta$-like cells. Diabetes 201362 2821-2833. (https://doi.org/10.2337/db12-1256)

53 Lima MJ, Muir KR, Docherty HM, McGowan NWA, Forbes S, Heremans Y, Heimberg H, Casey J \& Docherty K. Generation of functional beta-like cells from human exocrine pancreas. PLOS ONE 201611 e0156204. (https://doi.org/10.1371/journal.pone.0156204)

54 Lemper M, Leuckx G, Heremans Y, German MS, Heimberg H, Bouwens L \& Baeyens L. Reprogramming of human pancreatic exocrine cells to $\beta$-like cells. Cell Death and Differentiation 201522 1117-1130. (https://doi.org/10.1038/cdd.2014.193)

55 Baeyens L, De Breuck S, Lardon J, Mfopou JK, Rooman I \& Bouwens L. In vitro generation of insulin-producing beta cells from adult exocrine pancreatic cells. Diabetologia 200548 49-57. (https:// doi.org/10.1007/s00125-004-1606-1)

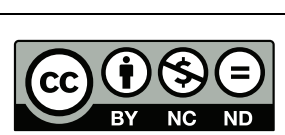

This work is licensed under a Creative Commons Attribution-NonCommercial-NoDerivatives 4.0 International License. 
56 Baeyens L, Lemper M, Leuckx G, De Groef S, Bonfanti P, Stangé G, Shemer R, Nord C, Scheel DW, Pan FC, et al. Transient cytokine treatment induces acinar cell reprogramming and regenerates functional beta cell mass in diabetic mice. Nature Biotechnology 2013 32 76-83. (https://doi.org/10.1038/nbt.2747)

57 Sasaki S, Miyatsuka T, Matsuoka T, Takahara M, Yamamoto Y, Yasuda T, Kaneto H, Fujitani Y, German MS, Akiyama H, et al. Activation of GLP-1 and gastrin signalling induces in vivo reprogramming of pancreatic exocrine cells into beta cells in mice. Diabetologia 201558 2582-2591. (https://doi.org/10.1007/s00125-015-3728-z)

58 Bonner-Weir S, Toschi E, Inada A, Reitz P, Fonseca SY, Aye T \& Sharma A. The pancreatic ductal epithelium serves as a potential pool of progenitor cells. Pediatric Diabetes 20045 16-22. (https://doi. org/10.1111/j.1399-543X.2004.00075.x)

59 Xu X, D’Hoker J, Stangé G, Bonné S, De Leu N, Xiao X, Van de Casteele M, Mellitzer G, Ling Z, Pipeleers D, et al. $\beta$ Cells can be generated from endogenous progenitors in injured adult mouse pancreas. Cell 2008 132 197-207. (https://doi.org/10.1016/j.cell.2007.12.015)

60 Bonner-Weir S, Inada A, Yatoh S, Li W-C, Aye T, Toschi E \& Sharma A. Transdifferentiation of pancreatic ductal cells to endocrine $\beta$-cells. Biochemical Society Transactions 200836 353-356. (https://doi. org/10.1042/BST0360353)

61 Corritore E, Dugnani E, Pasquale V, Misawa R, Witkowski P, Lei J, Markmann J, Piemonti L, Sokal EM, Bonner-Weir S, et al. $\beta$-Cell differentiation of human pancreatic duct-derived cells after in vitro expansion. Cellular Reprogramming 201416 456-466. (https://doi. org/10.1089/cell.2014.0025)

62 Zhang M, Lin Q, Qi T, Wang T, Chen C-C, Riggs AD \& Zeng D. Growth factors and medium hyperglycemia induce Sox9+ ductal cell differentiation into $\beta$ cells in mice with reversal of diabetes. PNAS 2016113 650-655. (https://doi.org/10.1073/pnas.1524200113)

63 Solar M, Cardalda C, Houbracken I, Martín M, Maestro MA, De Medts N, Xu X, Grau V, Heimberg H, Bouwens L, et al. Pancreatic exocrine duct cells give rise to insulin-producing $\beta$ cells during embryogenesis but not after birth. Developmental Cell 200917 849-860. (https://doi.org/10.1016/j.devcel.2009.11.003)

64 Kopp JL, Dubois CL, Schaffer AE, Hao E, Shih HP, Seymour PA, Ma J \& Sander M. Sox9+ ductal cells are multipotent progenitors throughout development but do not produce new endocrine cells in the normal or injured adult pancreas. Development 2011138 653-665. (https://doi.org/10.1242/dev.056499)

65 Kopinke D, Brailsford M, Shea JE, Leavitt R, Scaife CL \& Murtaugh LC. Lineage tracing reveals the dynamic contribution of Hes1+ cells to the developing and adult pancreas. Development 2011 138 431-441. (https://doi.org/10.1242/dev.053843)

66 Rankin MM, Wilbur CJ, Rak K, Shields EJ, Granger A \& Kushner JA. $\beta$-Cells are not generated in pancreatic duct ligation-induced injury in adult mice. Diabetes 201362 1634-1645. (https://doi.org/10.2337/ db12-0848)

67 Horb ME, Shen CN, Tosh D \& Slack JMW. Experimental conversion of liver to pancreas. Current Biology 200313 105-115. (https://doi. org/10.1016/S0960-9822(02)01434-3)

68 Meivar-Levy I \& Ferber S. Reprogramming of liver cells into insulinproducing cells. Best Practice and Research: Clinical Endocrinology and Metabolism 201529 873-882. (https://doi.org/10.1016/j. beem.2015.10.006)

69 Ferber S, Halkin A, Cohen H, Ber I, Einav Y, Goldberg I, Barshack I, Seijffers R, Kopolovic J, Kaiser N, et al. Pancreatic and duodenal homeobox gene 1 induces expression of insulin genes in liver and ameliorates streptozotocin-induced hyperglycemia. Nature Medicine 20006 568-572. (https://doi.org/10.1038/75050)

70 Ber I, Shternhall K, Perl S, Ohanuna Z, Goldberg I, Barshack I, Benvenisti-Zarum L, Meivar-Levy I \& Ferber S. Functional, persistent, and extended liver to pancreas transdifferentiation. Journal of Biological Chemistry 2003278 31950-31957. (https://doi. org/10.1074/jbc.M303127200)
71 Berneman-Zeitouni D, Molakandov K, Elgart M, Mor E, Fornoni A, Domínguez MR, Kerr-Conte J, Ott M, Meivar-Levy I \& Ferber S. The temporal and hierarchical control of transcription factors-induced liver to pancreas transdifferentiation. PLOS ONE 20149 e87812. (https://doi.org/10.1371/journal.pone.0087812)

72 Wang AY, Ehrhardt A, Xu H \& Kay MA. Adenovirus transduction is required for the correction of diabetes using Pdx-1 or neurogenin-3 in the liver. Molecular Therapy 200715 255-263. (https://doi. org/10.1038/sj.mt.6300032)

73 Yechoor V, Liu V, Paul A, Lee J, Buras E, Ozer K, Samson S \& Chan L. Gene therapy with neurogenin 3 and betacellulin reverses major metabolic problems in insulin-deficient diabetic mice. Endocrinology 2009150 4863-4873. (https://doi.org/10.1210/ en.2009-0527)

74 Banga A, Akinci E, Greder LV, Dutton JR \& Slack JMW. In vivo reprogramming of Sox9+ cells in the liver to insulin-secreting ducts. PNAS 2012109 15336-15341. (https://doi.org/10.1073/ pnas.1201701109)

75 Cerdá-Esteban N, Naumann H, Ruzittu S, Mah N, Pongrac IM, Cozzitorto C, Hommel A, Andrade-Navarro MA, Bonifacio E $\&$ Spagnoli FM. Stepwise reprogramming of liver cells to a pancreas progenitor state by the transcriptional regulator Tgif2. Nature Communications 20178 14127. (https://doi.org/10.1038/ ncomms14127)

76 Schonhoff SE, Giel-Moloney M \& Leiter AB. Neurogenin 3-expressing progenitor cells in the gastrointestinal tract differentiate into both endocrine and non-endocrine cell types. Developmental Biology 2004 270 443-454. (https://doi.org/10.1016/j.ydbio.2004.03.013)

77 Talchai C, Xuan S, Kitamura T, DePinho RA \& Accili D. Generation of functional insulin-producing cells in the gut by Foxo1 ablation. Nature Genetics 201244 406-412. (https://doi.org/10.1038/ng.2215)

78 Bouchi R, Foo KS, Hua H, Tsuchiya K, Ohmura Y, Sandoval PR, Ratner LE, Egli D, Leibel RL \& Accili D. FOXO1 inhibition yields functional insulin-producing cells in human gut organoid cultures. Nature Communications 20145 4242. (https://doi.org/10.1038/ ncomms5242)

79 Chen Y-J, Finkbeiner SR, Weinblatt D, Emmett MJ, Tameire F, Yousefi M, Yang C, Maehr R, Zhou Q, Shemer R, et al. De novo formation of insulin-producing 'Neo- $\beta$ cell islets' from intestinal crypts. Cell Reports 20146 1046-1058. (https://doi.org/10.1016/j. celrep.2014.02.013)

80 Hsu PD, Lander ES \& Zhang F. Development and applications of CRISPR-Cas9 for genome engineering. Cell 2014157 1262-1278. (https://doi.org/10.1016/j.cell.2014.05.010)

81 Hilton IB, D'Ippolito AM, Vockley CM, Thakore PI, Crawford GE, Reddy TE \& Gersbach CA. Epigenome editing by a CRISPR-Cas9based acetyltransferase activates genes from promoters and enhancers. Nature Biotechnology 201533 510-517. (https://doi. org/10.1038/nbt.3199)

82 Liao H-K, Hatanaka F, Araoka T, Reddy P, Wu MZ, Sui Y, Yamauchi T, Sakurai M, O'Keefe DD, Núñez-Delicado E, et al. In vivo target gene activation via CRISPR/Cas9-mediated trans-epigenetic modulation. Cell 2017171 1495.e15-1507.e15. (https://doi.org/10.1016/j. cell.2017.10.025)

83 Bradley A, Evans M, Kaufman MH \& Robertson E. Formation of germ-line chimaeras from embryo-derived teratocarcinoma cell lines. Nature 1984309 255-256. (https://doi.org/10.1038/309255a0)

84 Kobayashi T, Yamaguchi T, Hamanaka S, Kato-Itoh M, Yamazaki Y, Ibata M, Sato H, Lee YS, Usui J, Knisely AS, et al. Generation of rat pancreas in mouse by interspecific blastocyst injection of pluripotent stem cells. Cell 2010142 787-799. (https://doi.org/10.1016/j. cell.2010.07.039)

85 Usui J, Kobayashi T, Yamaguchi T, Knisely AS, Nishinakamura R \& Nakauchi H. Generation of kidney from pluripotent stem cells via blastocyst complementation. American Journal of Pathology 2012180 2417-2426. (https://doi.org/10.1016/j.ajpath.2012.03.007) 
86 Rashid T, Kobayashi T \& Nakauchi H. Revisiting the flight of Icarus: making human organs from PSCs with large animal chimeras. Cell Stem Cell 201415 406-409. (https://doi.org/10.1016/j.stem.2014.09.013)

87 Bourret R, Martinez E, Vialla F, Giquel C, Thonnat-Marin A \& De Vos J. Human-animal chimeras: ethical issues about farming chimeric animals bearing human organs. Stem Cell Research and Therapy 20167 87. (https://doi.org/10.1186/s13287-016-0345-9)

88 James D, Noggle SA, Swigut T \& Brivanlou AH. Contribution of human embryonic stem cells to mouse blastocysts. Developmental Biology 2006 295 90-102. (https://doi.org/10.1016/j.ydbio.2006.03.026)

89 Gafni O, Weinberger L, Mansour AA, Manor YS, Chomsky E, BenYosef D, Kalma Y, Viukov S, Maza I, Zviran A, et al. Derivation of novel human ground state naive pluripotent stem cells. Nature 2013 504 282-286. (https://doi.org/10.1038/nature12745)
90 Yamaguchi T, Sato H, Kato-Itoh M, Goto T, Hara H, Sanbo M, Mizuno N, Kobayashi T, Yanagida A, Umino A, et al. Interspecies organogenesis generates autologous functional islets. Nature 2017 542 191-196. (https://doi.org/10.1038/nature21070)

$91 \mathrm{Wu}$ J, Platero-Luengo A, Sakurai M, Sugawara A, Gil MA, Yamauchi T, Suzuki K, Bogliotti YS, Cuello C, Morales Valencia M, et al. Interspecies chimerism with mammalian pluripotent stem cells. Cell 2017168 473.e15-486.e15. (https://doi.org/10.1016/j. cell.2016.12.036)

92 Vilarino M, Rashid ST, Suchy FP, McNabb BR, van der Meulen T, Fine EJ, Ahsan S, Mursaliyev N, Sebastiano V, Diab SS, et al. CRISPR/ Cas9 microinjection in oocytes disables pancreas development in sheep. Scientific Reports 20177 17472. (https://doi.org/10.1038/ s41598-017-17805-0)

Received in final form 26 February 2018

Accepted 27 February 2018 http://www.endocrineconnections.org https://doi.org/10.1530/EC-18-0012
(C) 2018 The authors Published by Bioscientifica Ltd 